\title{
Sustainable Hospital Design for Sustainable Development
}

\author{
Dicle Aydın ${ }^{1}$, Esra Yaldız ${ }^{2}$ and Suheyla Buyuksahin ${ }^{3}$ \\ ${ }^{1,2}$ Necmettin Erbakan University, Faculty of Eng.and Arc. Department of Architecture, Turkey \\ ${ }^{3}$ Selcuk University, Faculty of Architecture Department of Architecture, Turkey
}

\begin{abstract}
Sustainability is the important concepts in $20^{\text {th }}$ century. Several definitions of sustainable development have been put forth, including the following common one: development that meets the needs of the present without compromising the ability of future generations to meet their own needs. Sustainability relies on high efficiency and the uninterrupted function of a continuing social, economic and ecological system in such a way that does not degrade and consume the resources used. Sustainable architecture is explained as a long term thought and action philosophy including the processes of building programming, usage, management throughout its economic life, destruction of the building or reuse. "The characteristics of sustainable design are its ability to integrate the life cycles of building systems with ecological systems in biosphere. The aim of this study is to reveal what design inputs can be driven in hospital buildings that differ in terms of design, application process and human environment relationships in use. When the continuously dense usage situations of hospitals are considered, the concept of "green hospital" is used to define the hospitals fulfilling at least one of the alternatives such as choosing environmental settlement design, buying nature friendly building materials and products, being environmentally sensitive during the construction of the hospital building and keeping this sensitivity going in service production process. Green hospital defines a facility which recycles, reuses the materials, reducing wastes and giving more clean air to the environment. This approach based on an environmentalist management understanding is seen under the headlines like management of waste and hazardous materials, water management, energy management and air emission regulating system and innovator environmental designs.
\end{abstract}

Keywords: sustainability, hospital building, sustainable hospital, sustainable development.

\section{Introduction}

Sustainability is one of the important concepts in $20^{\text {th }}$ century. Several definitions of sustainable development have been put forth, including the following common one: development that meets the needs of the present without compromising the ability of future generations to meet their own needs [1]. Sustainability is a key concept aiming high efficiency and predicting the ceaseless continuance of a social, economic and ecological system's functions without demolishing or consuming the used sources [2] [3].

The artificial environments created by humans are directly or indirectly responsible for the majority of the damages on atmosphere, the earth and the underground. The artificial environment, which also creates pressure on ecological balances, has effects on different scales [4]. Figure 1. summarizes these effects schematically.

Architecture exists as discipline effective on the formation of artificial environment.The physical quality of artificial environments, human-environment relations and the environmental conditions' factors on forming artificial environment gain importance as the criteria of architectural design for evaluation and formation. The existence of the human - as a part of the whole and the space/spaces he used without demolishing the ecosystem and causing excessive consumption of limited natural resources explains the sustainability concept in architecture.

The aim of this study is to reveal what design inputs can be driven in hospital buildings that differ in terms of design, application process and human environment relationships in use. 


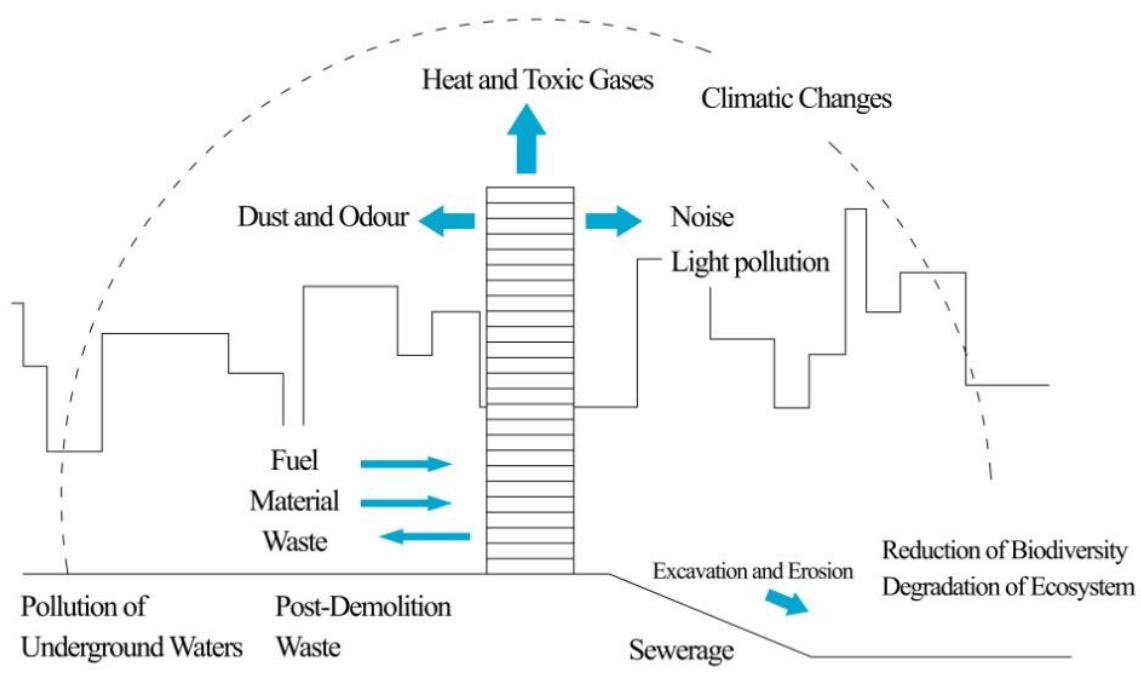

Fig. 1. The effects of artificial environment on natural systems [4](Gökmeral, 2014).

\section{Sustainable Architecture}

Sustainable architecture is explained as a long term thought and action philosophy including the processes of building programming, usage, management throughout its economic life, destruction of the building or reuse. "The characteristics of sustainable design are its ability to integrate the life cycles of building systems with ecological systems in biosphere. Building components and energy systems must work in harmony with ecological systems in such a way that they will cause minimal effect on environment - from source to the smallest equipment in the building. A successful ecological (green) building should create minimum destructive maximum positive effect on the natural systems" [5].

Main aims of the sustainable architecture are:

-long-life building design that can adapt to flexible and changing conditions

-efficient use of limited natural resources

-use of renewable energy sources

-reduction of waste

-Minimizing health and safety risks

-ensuring healthy indoor air quality

-taking measures to reduce environmental pollution

-protection of biodiversity [4][6][7][8][9].

The relations of the buildings with the environment can be at different levels according to their functions. The interaction of an educational building or a detached dwelling or a factory with the environment is different. Hospitals on the other hand is seen as a major management making service production, a complex building including different functions, a dense building housing various users and a continuously revolving and changing building where medical technological equipment is used. Addition to these characteristics, hospitals are the type of buildings where energy and water consumption is high, the amount of chemical and non-chemical waste is huge, the output of potential hazardous material is high, the number of bought materials is various and many, waste storage and extirpation areas are required and it is obligatory to use renewable energy resources for sustainability.

When the criteria to be sustainable is embraced, the compelling and specialist characteristic of hospital design revives the combination of the information coming from different specialty areas in design. In such a 
team work the effective use of information becomes crucially important. Figure 2 defines the building layers with the aim of effective use of information.
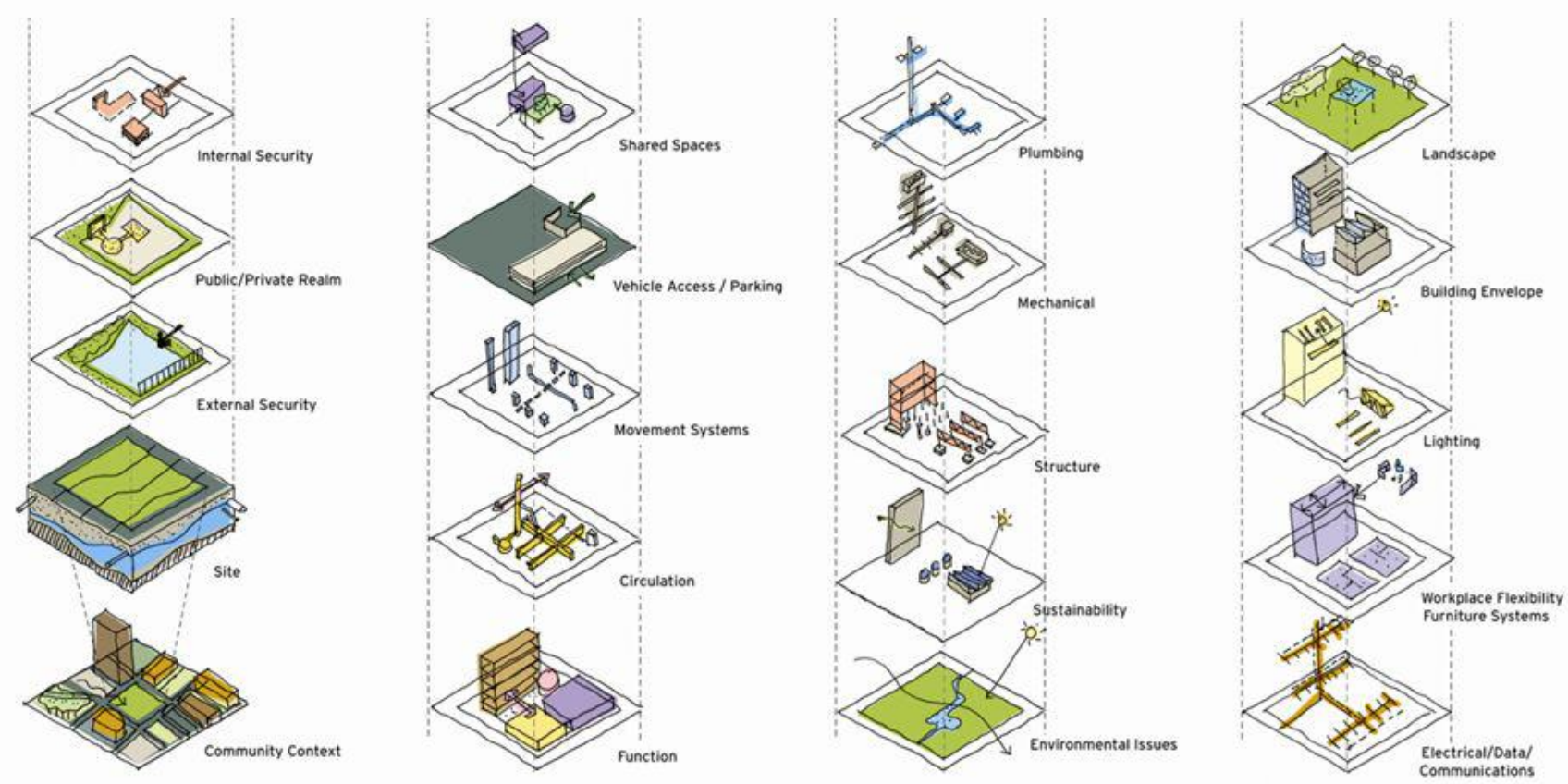

Fig. 2. Building design levels [10].

The new approaches like "green (ecological) hospital", "healing hospital" are mentioned in current hospital designs. When the continuously dense usage situations of hospitals are considered, the concept of "green hospital" is used to define the hospitals fulfilling at least one of the alternatives such as choosing environmental settlement design, buying nature friendly building materials and products, being environmentally sensitive during the construction of the hospital building and keeping this sensitivity going in service production process. Green hospital defines a facility which recycles, reuses the materials, reducing wastes and giving more clean air to the environment. This approach based on an environmentalist management understanding is seen under the headlines like management of waste and hazardous materials, water management, energy management and air emission regulating system and innovator environmental designs [11] (Figure 3). Reuse of the waste and hazardous materials (depending on the building management decisions), reuse of the waste water and rain waters, landscape elements selected to reduce water consumption are architectural design decisions. The use of solar energy in hospital buildings with high amount of energy consumption, choosing appropriate window materials for thermal conservation, making more use of day light are also other architectural design decisions. At the same time, the reduction of polluting gas release, usage of waste thermal recycling systems for heating and cooling provide energy saving.

"Healing hospital" understanding handled as "patient centered" not "care centered" defines innovative environmental designs and aims at patient friendly and non-scary hospital environments. In this scope; designers entered the process of changing patient, staff and visitor experiences by designing healing, improving, relaxing and friendly welcoming spaces. Natural mediums gained importance [12], the designs which cares user satisfaction and can be naturally aerated and lightened are adopted. In spite of that making use of environmental factors in architectural design (use of day light, use of dominant wind as an input in design, use of topography, visually improving the environmental quality, enriching vegetation, increasing landscape) is important for any building design, it becomes more important in health buildings. 


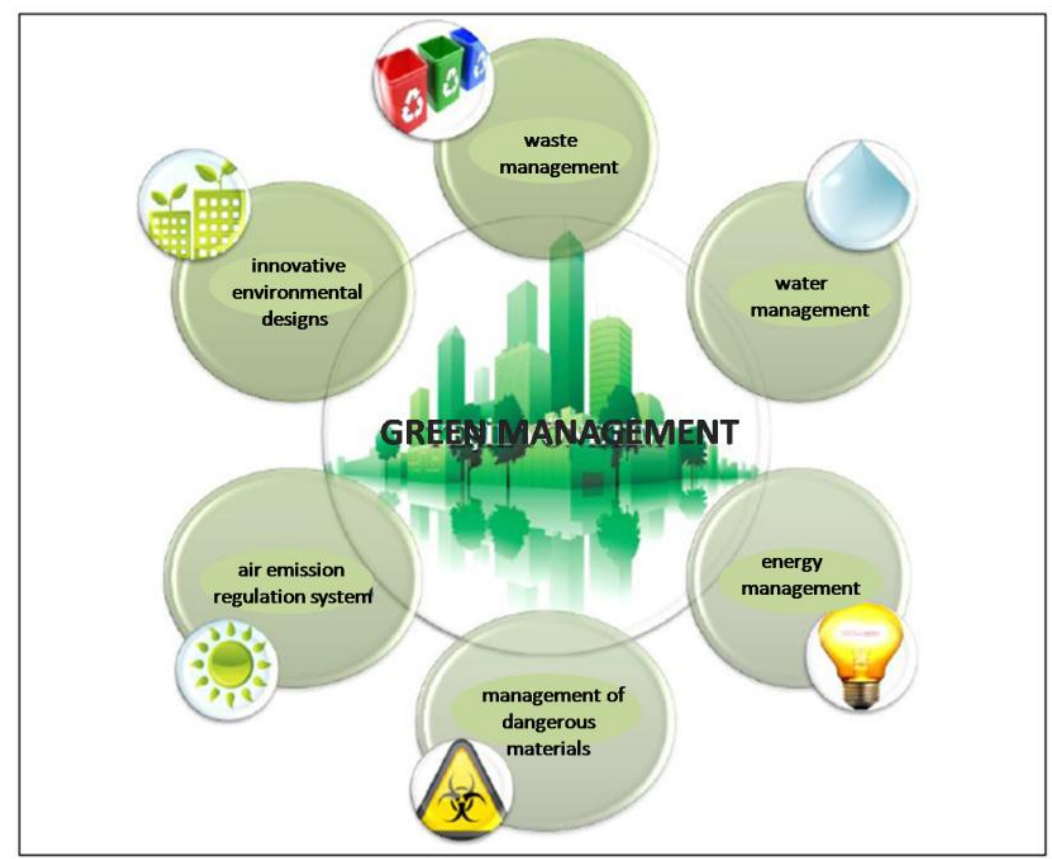

Fig. 3. Key elements of green management [11].

\section{Acknowledgements}

This study was supported by Necmettin Erbakan University Coordinator ship of Scientific Research Projects with 172518001-1091 project number.

\section{References}

[1] M. O. Abdeen, 2008, "Energy, Environment and Sustainable Development", Renewable and Sustainable Energy Reviews, Vol:12, Issuu:9, pp:2265-2300

[2] A. Atıl, B. Gülgün and İ. Yörük, "Sürdürülebilir Kentler ve Peyzaj Mimarllğl”, Ege Üniv. Ziraat Fakültesi Dergisi, 42(2): 215-226, 2005.

[3] D. Aydın, "Socio-Cultural Sustainability and an Assessing model for Reuse Adaptation", CESB 2010, Central Europe Towards Sustainable Buildings, from Theory to Buildings, 30 Jun- 2 July, Prague, Czech Republic, 2010, p: 531-534

[4] E. B. Gökmeral, "Sürdürülebilir ve Bütünleşik Bina Tasarım Süreçlerinde Iç Mimarllk”, Mimar Sinan Güzel Sanatlar Üniversitesi, Fen Bilimleri Enstitüsü, Yüksek Lisans Tezi, 2014.

[5] K. Yeang, "Ken Yeang” (Green Architecture), Architectural Design, 2001, V: 71, N:4, 60

[6] K. Yeang, "The Green Shyscraper: The Basis for Designing Sustainable Intensive Building”, Munich:Prestel Verlag, 1999.

[7] L. Bourdeau, "National Report: Sustainable Develeoment and Future of Construction in France", France: V-Centre Scientifique Et Technique Du Batıment. 1999.

[8] CIB, “Agenda 21 on Sustainable Construction", Rotterdam: CIB Report Publication 237. 1999.

[9] WGSC, Working Group for Sustainable Construction - WGSC, 2004. "Working Group Sustainable Construction Methods and Techniques Final Report”. 2004.

[10]E. Krygiel and B. Nies,. Green BIM: Successful Sustainable Design with Building Information Modelling, Wiley, 2008.

[11]O. Özkan, G. Bayın, T.G. Yeşilaydın, "Hastane Yönetiminde Sürdürülebilir Yaklaşım: Yeşil Yönetim", Sağlık ve Hastane İdaresi 8. Kongresi, 10-12 Eylül, 2014, Lefke Avrupa Üniversitesi Sağlık Bilimleri Fakültesi, 2014, pp: 22382248

[12] Ergenoğlu, A.S.; Aytuğ, A., "Sağllk Kurumlarında Değişen Paradigmalar ve İyileştiren Hastane Kavramının Mimari Tasarım Açısından İrdelenmesi”, Megaron, YTÜ Mim. Fak. E-Journal YTÜ Arch. Fac. E-Journal, 2007, Vol.2, Issuu 1, pp:44-63 